\title{
Influences of Climate Change on Water Resources Availability in Jinjiang Basin, China
}

\author{
Wenchao Sun, ${ }^{1}$ Jie Wang, ${ }^{2}$ Zhanjie Li, ${ }^{1}$ Xiaolei Yao, ${ }^{1}$ and Jingshan Yu ${ }^{1}$ \\ ${ }^{1}$ College of Water Sciences, Beijing Normal University, Xinjiekouwai Street 19, Beijing 100875, China \\ ${ }^{2}$ Interdisciplinary Graduate School of Medicine and Engineering, University of Yamanashi, 4-3-11, Takeda, Kofu, \\ Yamanashi 400-8511, Japan \\ Correspondence should be addressed to Jingshan Yu; jsyu.bnu@gmail.com
}

Received 30 August 2013; Accepted 8 January 2014; Published 17 February 2014

Academic Editors: A. Billi and H. Steffen

Copyright (C) 2014 Wenchao Sun et al. This is an open access article distributed under the Creative Commons Attribution License, which permits unrestricted use, distribution, and reproduction in any medium, provided the original work is properly cited.

\begin{abstract}
The influences of climate change on water resources availability in Jinjiang Basin, China, were assessed using the Block-wise use of the TOPmodel with the Muskingum-Cunge routing method (BTOPMC) distributed hydrological model. The ensemble average of downscaled output from sixteen GCMs (General Circulation Models) for AlB emission scenario (medium $\mathrm{CO}_{2}$ emission) in the 2050s was adopted to build regional climate change scenario. The projected precipitation and temperature data were used to drive BTOPMC for predicting hydrological changes in the 2050s. Results show that evapotranspiration will increase in most time of a year. Runoff in summer to early autumn exhibits an increasing trend, while in the rest period of a year it shows a decreasing trend, especially in spring season. From the viewpoint of water resource availability, it is indicated that it has the possibility that water resources may not be sufficient to fulfill irrigation water demand in the spring season and one possible solution is to store more water in the reservoir in previous summer.
\end{abstract}

\section{Introduction}

Chinese economic boom in the past two decades brings a rapid increase in the demand of water resources. Annual water use rose from 522 billion $\mathrm{m}^{3}$ in 1993 to 611 billion $\mathrm{m}^{3}$ in 2011 [1]. Due to the impact of climate change and human activity, the uncertainty in water resource availability would likely be much higher in the 21st century [2]. Shortage of water resources is turning into a limiting factor to the sustainable economic development gradually in China [3]. It even happens in the humid area of China, due to intra-annual mismatch between water resources availability and consumption demand, especially in the spring season [4]. The Quanzhou City in Fujian Province, for which water supply highly relies on the surface water resources in Jinjiang Basin, is a typical area suffering from such mismatch. Two severe droughts have been reported in 2009 [5], which causes damages to the agriculture and industry. In such context, predicting hydrological changes under climate change is vital for making countermeasures against potential water resource shortage.
The objective of this study is to assess the impacts of climate change on the water resources availability in the Jinjiang Basin. The assessment about impacts of climate change on hydrological processes at basin scale usually involves building future regional climate scenario based on downscaled output of general circulation models (GCMs) and subsequently using the projected future meteorological data to drive hydrological models for making prediction. In this study, firstly, a grid-based distributed hydrological model Block-wise use of the TOPmodel with the Muskingum-Cunge routing method (BTOPMC) was applied to the Jinjiang Basin and calibrated based on streamflow data. Then the regional climate change scenario obtained from downscaled GCMs was used as the input of BTOPMC for predicting hydrological processes in the mid-21st century. At last, influences of climate changes on water resources availability in Jinjiang Basin were evaluated and some conclusions were drawn.

\section{The Study Area}

Quanzhou is a coastal city in the Western Taiwan Straits Economic Zone of China. The whole area of the Jinjiang Basin is 


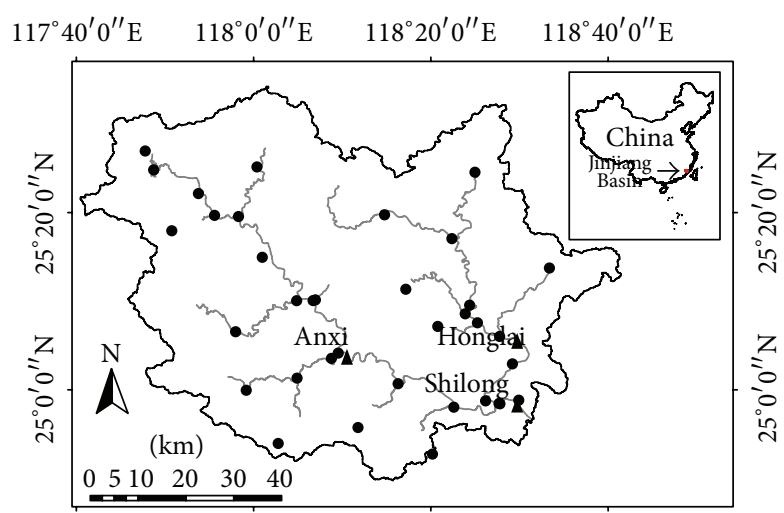

$117^{\circ} 40^{\prime} 0^{\prime \prime} \mathrm{E} \quad 118^{\circ} 0^{\prime} 0^{\prime \prime} \mathrm{E} \quad 118^{\circ} 20^{\prime} 0^{\prime \prime} \mathrm{E} \quad 118^{\circ} 40^{\prime} 0^{\prime \prime} \mathrm{E}$

- Rainfall stations

\ Streamflow stations

— Rivers

FIgURE 1: The river network, locations of streamflow stations and rainfall stations in Jinjiang Basin.

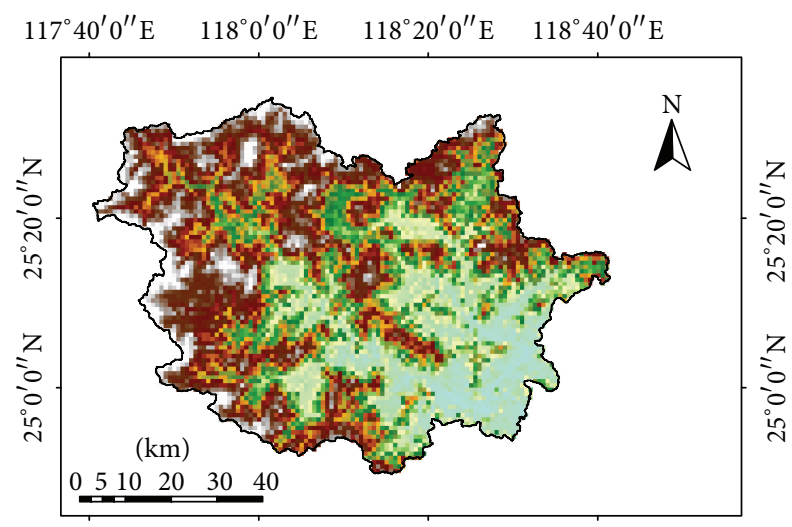

$117^{\circ} 40^{\prime} 0^{\prime \prime} \mathrm{E} \quad 118^{\circ} 0^{\prime} 0^{\prime \prime} \mathrm{E} \quad 118^{\circ} 20^{\prime} 0^{\prime \prime} \mathrm{E} \quad 118^{\circ} 40^{\prime} 0^{\prime \prime} \mathrm{E}$

High: 1375

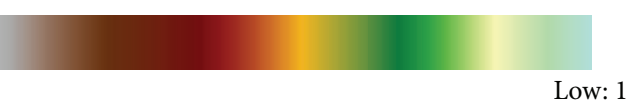

Elevation $(\mathrm{m})$

FIgURE 2: Topography of Jinjiang Basin.

within the Quanzhou City. The river has two major tributaries (Figure 1), named as Xixi and Dongxi, which join together at Shuangxikou. The basin area is $5629 \mathrm{~km}^{2}$. It combines the mountainous area in the northwest and the low plain region in the southeast part of the basin. The elevation varies from 1 to $1375 \mathrm{~m}$ (Figure 2). The dominating land use types are forest and crop land. The basin has a subtropical monsoon climate characterized by dry winter season and rainy summer season. The annual precipitation ranges from $1000 \mathrm{~mm}$ to $1800 \mathrm{~mm}$, for which $80 \%$ occurs in the period of March to September. The water intake infrastructure at Jinji sluice, which is located in several kilometers downstream the Shilong gauging station, makes major contributions to the water supply in Quanzhou City. The evaluation of water resources availability will be carried out based on the simulation of streamflow in the Shilong station.

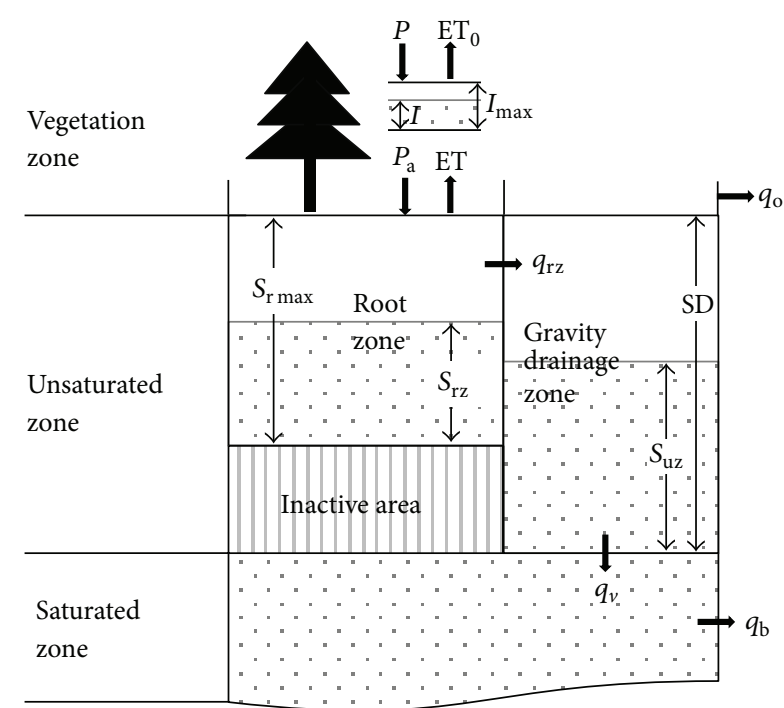

FIgURE 3: The schematic description of BTOPMC structure for runoff generation at each grid, where $P$ is gross precipitation, $I_{\max }$ is maximum interception capacity, $I$ is interception state, $\mathrm{ET}_{0}$ is interception evaporation, ET is evapotranspiration from soil water, $S_{\mathrm{rmax}}$ is maximum root zone storage capacity, $S_{\mathrm{rz}}$ is soil water in root zone, $q_{\mathrm{rz}}$ is soil water moving from root zone to gravity drainage zone, $\mathrm{SD}$ and $S_{\mathrm{uz}}$ are soil water deficit and state in gravity drainage zone, $q_{v}$ is groundwater recharge, $q_{\mathrm{o}}$ is overland flow, and $q_{\mathrm{b}}$ is base flow.

\section{The Hydrological Model}

3.1. Model Description. The BTOPMC model is a physically based distributed hydrological model (see $[6,7]$ for details). The model has been successfully applied in many basins located in the Asian Monsoon area (e.g., [6, 8-10]). It divides the whole basin into many grid cells to account for spatial heterogeneity within the basin. At the same time, the grid cells are grouped into several blocks in order to keep the model structure in a relative simple manner. The runoff generation methodology is similar to TOPmodel [11]. The Muskingum-Cunge method [12] is employed for runoff routing. The BTOPMC considers saturation excess runoff, extending the TOPMODEL concept in a grid based framework for distributed hydrological simulation of large river basins.

As shown in Figure 3, the vertical column of each grid includes vegetation zone, unsaturated zone, and saturated zone. The rainfall is first intercepted by the canopy in the vegetation zone for evaporation. Then the net rainfall is received by the unsaturated zone. In order to describe the complexity of hydrological processes in the unsaturated zone, it is further divided. The root zone and inactive zone represent the soil water storage between field capacity and wilting point. And only the portion in root zone can be used by vegetation. Net rainfall is assumed to infiltrate into the root zone until the field capacity is reached. The gravity drainage zone reflects the soil moisture between saturation and field capacity, which receives excess water from root zone. The overland runoff occurs when the soil water in the gravity drainage zone reaches saturation. The saturation zone receives recharge 
TABLE 1: Data used in BTOPMC modeling in Jinjiang Basin.

\begin{tabular}{|c|c|c|}
\hline Type & Description & Remark \\
\hline \multirow{7}{*}{ Physical data } & Digital elevation map (DEM) & $\begin{array}{l}\text { From GLOBE data, } 30 \text { arc second resolution } \\
\text { Available at: http://www.ngdc.noaa.gov/mgg/topo/globe.html }\end{array}$ \\
\hline & \multirow{2}{*}{ Land cover map } & From IGBP classified global data, $1 \mathrm{~km}$ resolution \\
\hline & & Available at: http://edc2.usgs.gov/glcc/globdoc2_0.php \\
\hline & \multirow{3}{*}{ Soil map } & From harmonized world soil database \\
\hline & & (FAO/IIASA/ISRIC/ISSCAS/JRC, 2012) [13] \\
\hline & & 30 arc second resolution \\
\hline & Soil texture & $\begin{array}{l}\text { From harmonized world soil database } \\
\text { (FAO/IIASA/ISRIC/ISSCAS/JRC, 2012) [13] }\end{array}$ \\
\hline \multirow{13}{*}{ Meteorological data } & Daily precipitation & From Bureau of Water Resources of Quanzhou City \\
\hline & \multirow{2}{*}{ Monthly precipitation } & From CRU 2.0 data set, input for the S-W model \\
\hline & & Available at: http://www.ipcc-data.org/obs/get_30yr_means.html \\
\hline & \multirow{2}{*}{ Monthly cloud cover } & From CRU 2.0 data set, input for the S-W model, \\
\hline & & Available at: http://www.ipcc-data.org/obs/get_30yr_means.html \\
\hline & \multirow{2}{*}{ Monthly diurnal temperature range } & From CRU 2.0 data set, input for the S-W model, \\
\hline & & Available at: http://www.ipcc-data.org/obs/get_30yr_means.html \\
\hline & \multirow{2}{*}{ Monthly vapour pressure } & From CRU 2.0 data set, input for the S-W model, \\
\hline & & Available at: http://www.ipcc-data.org/obs/get_30yr_means.html \\
\hline & \multirow{2}{*}{ Monthly wind speed } & From CRU 2.0 data set, input for the S-W model, \\
\hline & & Available at: http://www.ipcc-data.org/obs/get_30yr_means.html \\
\hline & Monthly daylight duration & $\begin{array}{l}\text { Calculated based on cloud cover, using the relationship of Doorenbos } \\
\text { and Pruitt [14], input for the S-W model }\end{array}$ \\
\hline & Monthly extraterrestrial radiation & $\begin{array}{l}\text { Calculated based on the location latitude and the date in the year, } \\
\text { using the method specified in Zhou et al. [15], input for the S-W } \\
\text { model }\end{array}$ \\
\hline Vegetation data & Monthly NDVI & GIMMS NDVI (Pinzonet al. [16]), input for the S-W model \\
\hline Hydrological data & Daily observed streamflow & From Bureau of Water Resources of Quanzhou City \\
\hline
\end{tabular}

from gravity drainage zone and releases baseflow in a nonlinear manner. The potential evapotranspiration, either from the interception (PET0) or from the soil water in the root zone (PET), is computed based on the Shuttleworth-Wallace (S-W) model developed by Zhou et al. [15], for which only publicly available data are introduced, easing the application in data scarce basin. The evaporation from interception is calculated as the less of PET0 and canopy intercepted water amount. And the evapotranspiration from soil is the less of PET and water in root zone. The input data are tabulated in Table 1.

3.2. Model Setup and Calibration. The upstream area of Shilong gauging station is selected for BTOPMC application. The study area is divided into three blocks based on the location of Honglai and Anxi Gauging station. In total seven parameters need to be calibrated as listed in Table 2. The parameters values of each block were obtained through calibration based on the observed streamflow at the corresponding gauging station in each block. The calibration and validation periods are 2003-2004 and 2005-2007, respectively. The NashSutcliffe Efficiency (NSE) and Volume Ratio (VR) are selected as model performance indicators:

$$
\begin{gathered}
\mathrm{NSE}=1-\frac{\sum\left(Q_{\mathrm{obs}, i}-Q_{\mathrm{sim}, i}\right)}{\sum\left(Q_{\mathrm{obs}, i}-Q_{\mathrm{obs}, a}\right)} \\
\mathrm{VR}=\frac{\sum Q_{\mathrm{sim}, i}}{\sum Q_{\mathrm{obs}, i}},
\end{gathered}
$$

where $Q_{\mathrm{obs}, i}$ and $Q_{\text {sim }, i}$ are the observed and simulated streamflows at time step $i$ and $Q_{\mathrm{obs}, i}$ is the average observed streamflow for the whole simulation period.

\section{The Future Scenarios of Climate Change}

The spatial scale of GCM output is too large to describe characteristics at basin scale; usually downscaling GCM is necessary [17]. Uncertainty of climate change projections from GCMs cannot be ignored $[18,19]$. To make a more reliable future regional climate change scenario, usually an ensemble analysis combing multiple GCM analysis and quantifying the probability of future climate is conducted. Considering the above-mentioned issue, the Climate Wizard dataset (available at: http://www.climatewizard.org/index.html), projections of future temperature and precipitation derived from ensemble average of 16 GCMs, is adopted in this study. The monthly precipitation and mean temperature was downscaled to the resolution of $50 \mathrm{~km}$ using an empirical statistical method (see [20] for details). The data of the 2050s (2040-2069) for A1B scenario (medium $\mathrm{CO}_{2}$ emission) was used to build regional climate change scenario of the mid-21st century in Jinjiang Basin. The ensemble average of downscaled monthly mean temperature was directly used as input to compute potential evapotranspiration in the 2050s. The percentage changes of monthly mean precipitation between 2050s and historical climate (past 50 years) were used to scale daily precipitation data for 2005-2009. Then the projected precipitation data 
TABLE 2: Model parameter description.

\begin{tabular}{|c|c|c|c|c|}
\hline Parameter & Description & Unit & Range & Value \\
\hline$T_{0}$ & Saturated transmissivity & $\mathrm{m}^{2} / \mathrm{h}$ & $0.1-200$ & $\begin{array}{l}\text { Sand: } 15 \\
\text { Silt: } 10 \\
\text { Clay: } 8\end{array}$ \\
\hline$m$ & Decay factor of transmissivity & - & $0.001-0.3$ & 0.02 \\
\hline$S_{\mathrm{r} \max }$ & Maximum root zone storage & $\mathrm{m}$ & $0.0001-0.8$ & $\begin{array}{c}\text { Forest: } 0.02 \\
\text { Grass: } 0.01 \\
\text { Cropland: } 0.01\end{array}$ \\
\hline$\alpha$ & Soil drying function parameter & - & $-3-8$ & 4 \\
\hline$n$ & Average Manning's coefficient & - & $0.001-0.4$ & 0.06 \\
\hline$\Delta t$ & Temporal discretization of flow in a channel segment & - & $1-8$ & 2 \\
\hline$\Delta l$ & Spatial discretization of a channel segment & - & $1-8$ & 6 \\
\hline
\end{tabular}

TABLE 3: Model performance at three streamflow stations.

\begin{tabular}{|c|c|c|c|c|c|c|}
\hline \multirow{2}{*}{$\begin{array}{l}\text { Station name } \\
\text { Criteria }\end{array}$} & \multicolumn{2}{|c|}{ Anxi } & \multicolumn{2}{|c|}{ Honglai } & \multicolumn{2}{|c|}{ Shilong } \\
\hline & NSE & VR & NSE & VR & NSE & VR \\
\hline $\begin{array}{l}\text { Calibration period } \\
(2005-2006)\end{array}$ & $84.0 \%$ & $96.3 \%$ & $63.3 \%$ & $111.0 \%$ & $78.6 \%$ & $110.2 \%$ \\
\hline $\begin{array}{l}\text { Validation period } \\
(2007-2009)\end{array}$ & $78.7 \%$ & $109.3 \%$ & $65.1 \%$ & $97.5 \%$ & $75.6 \%$ & $107.2 \%$ \\
\hline
\end{tabular}

was inputted to BTOPMC. The BTOMPC simulation corresponding to this regional climate change scenario represents characteristics of hydrological processes in the 2050s. The simulation for the period from 2005 to 2009 is considered as the baseline. The differences between the two simulations are considered as the impact of climate change on hydrological system.

Figure 4 demonstrates basin averaged relative changes of monthly mean precipitation and temperature between baseline and future climate scenario in the 2050s, respectively. The precipitation will increase from April to October. For the period from November to next March, the precipitation will decrease or remain almost the same with the baseline. For mean temperature in the 2050s scenario, it will increase with an average degree of $1.94^{\circ} \mathrm{C}$ in all of the twelve months.

\section{Results and Discussion}

5.1. The Performance of BTOPMC. The daily observed and simulated streamflow for the three gauging stations is shown in Figures 5, 6, and 7. It can be seen that the simulations can reproduce the timing and degree of streamflow variations fairly in each station. The values of NSE and VE for calibration and validation period are listed in Table 3, which indicates that simulation results are generally satisfying. The model performance in Honglai is lower than in the other two stations. One possible reason is that a reservoir named Shanmei is located in the upstream area of Honglai. However, due to the lack of the reservoir operation data, the impact of streamflow regulation was not considered in the simulation. As the most downstream station, the model performance at Shilong is slightly influenced by not considering the reservoir operation, which explains the simulation result at Shilong is worse than at Anxi (no reservoir in its upstream area) but better than at Honglai. As the impact of climate change will be explored at the monthly scale simulation at Shilong, the monthly simulated streamflow is also examined and demonstrated in Figure 8. The NSE is $93.1 \%$ for calibration period and $90.3 \%$ for validation period, respectively. The fairly well performance at both daily and monthly scales justifies the application of the calibrated model for the impact assessment being planned.

5.2. Influences of Climate Changes on Water Resources Availability. The daily meteorological data of 2050s A1B scenario, which was generated from downscaled ensemble prediction of 18 GCMs, were used as input of BTOPMC model for simulating hydrological processes in the future. The monthly relative changes of $\mathrm{ET}$ and runoff between the current situation (simulation from 2005 to 2009) and 2050s are depicted in Figure 9. The ET increases in the 2050s for all months, expect January. As mean temperatures in all months are higher in the 2050s, more energy is available for driving soil water and intercepted water to evaporate or transpire, which is the most probable reason of ET increasing in the eleven months. Meanwhile, the reduction of ET in January for 2050 scenario is considered as an outcome of sharp decrease of rainfall (13.3\%), which lowers the availability of water for evapotranspiration.

The runoff in the 2050s exhibits an increasing trend in summer to early autumn (July, August, September, and October), with degrees varying from 3.4\% (July) to $13.2 \%$ (September). This can be explained as a consequence of increasing rainfall in the same period. From November to June, the runoff in all of the eight months reduces compared with the current situation. For November, December, January, 


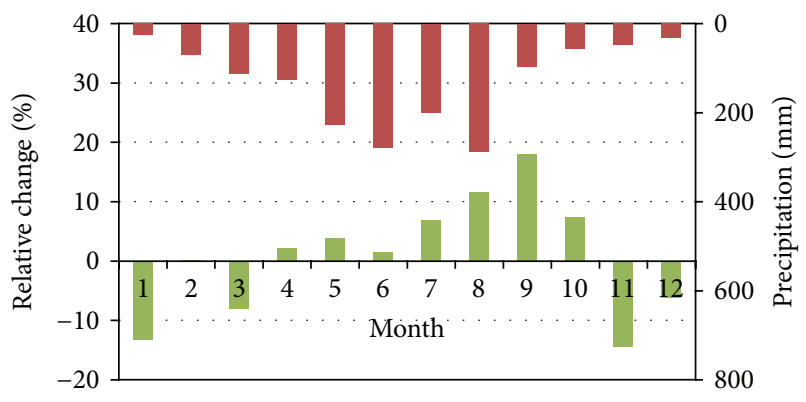

(a)

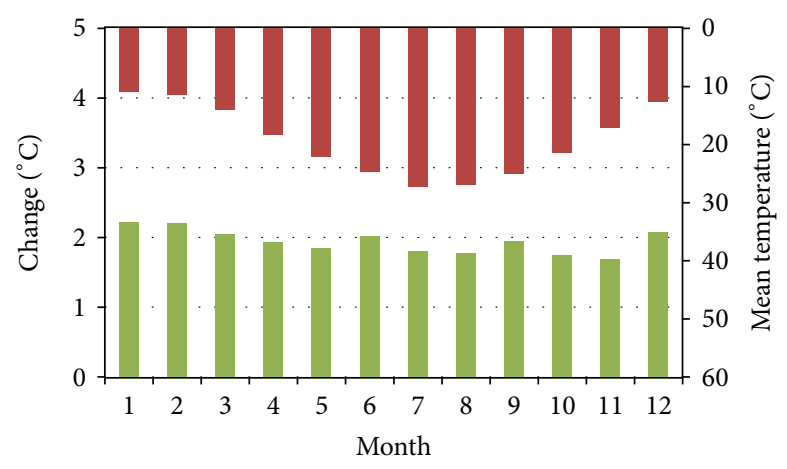

(b)

FIGURE 4: Basin averaged changes (green columns) of monthly mean precipitation and temperature between baseline (red columns) and future climate scenario in the 2050s.

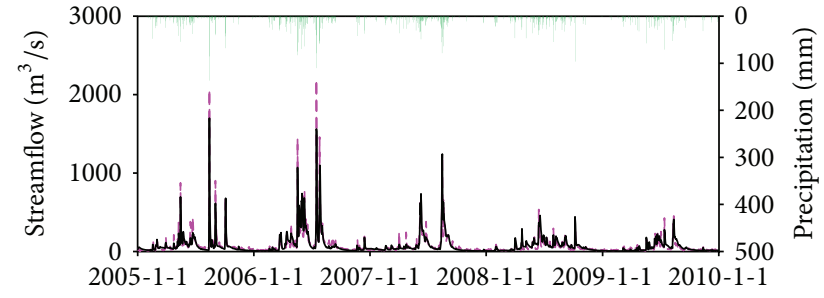

- $P$
$--Q_{\text {obs }}$
$-Q_{\text {sim }}$

FIgURE 5: Streamflow simulations at Anxi station, where $P$ is precipitation, $Q_{\mathrm{obs}}$ is observed streamflow, and $Q_{\text {sim }}$ is simulated streamflow by BTOPMC.

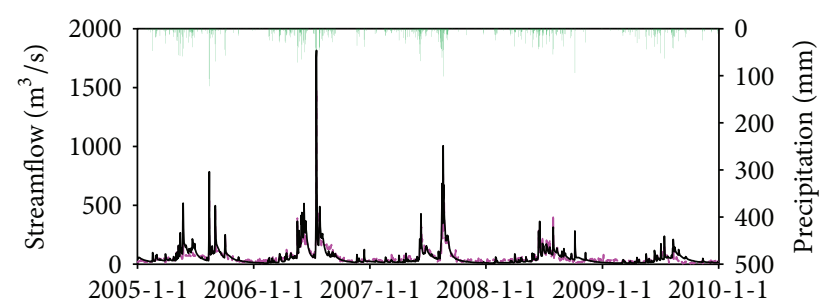

$$
\begin{aligned}
& \text { - } \\
& --Q_{\text {obs }}
\end{aligned}
$$

Figure 6: Streamflow simulations at Honglai station, where $P$ is precipitation, $Q_{\text {obs }}$ is observed streamflow, and $Q_{\text {sim }}$ is simulated streamflow by BTOPMC.

and March, it may result from the decreasing trend in rainfall. Due to the cumulative effects of rainfall reduction in previous months and higher ET, runoff in March decreases most, with an extent of $17.4 \%$. These effects could also work as the explanation of why the runoff decreases in February, April, May, and June, even if rainfall increases or remains almost the same with current situation.

From the viewpoint of water resource availability, it is demonstrated that especially in the spring season, available water resource decreases in the 2050s A1B scenario, which

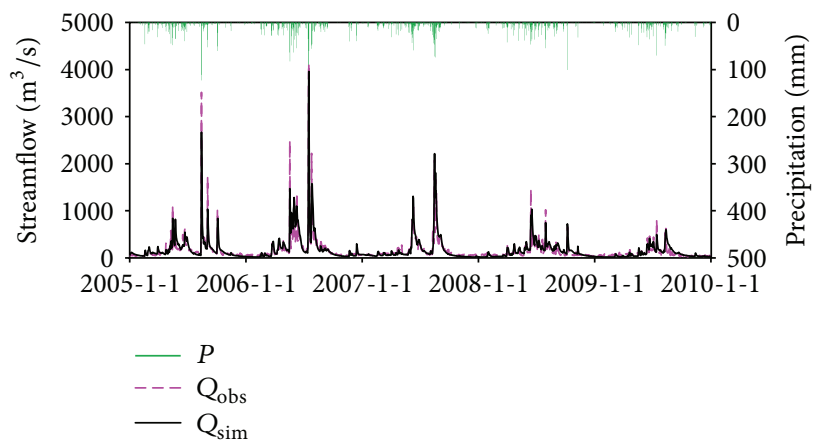

FIgURE 7: Streamflow simulations at Shilong station, where $P$ is precipitation, $Q_{\text {obs }}$ is observed streamflow, and $Q_{\text {sim }}$ is simulated streamflow by BTOPMC.

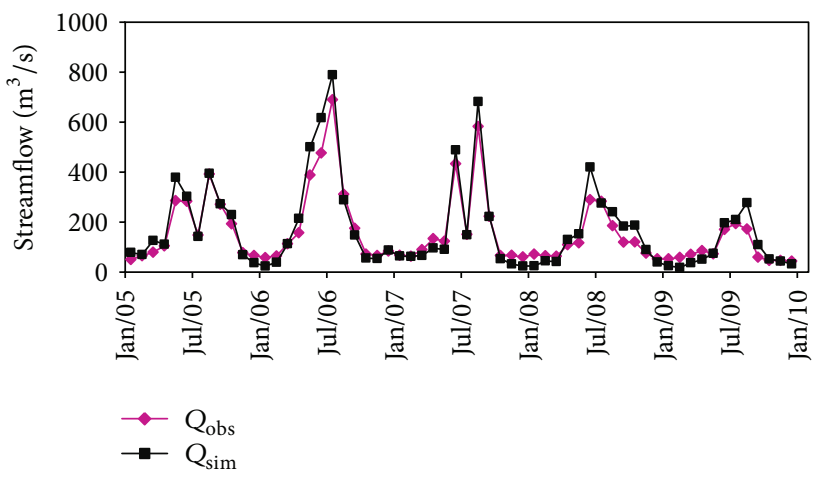

FIGURE 8: Comparison between monthly averaged simulated and observed streamflow at Shilong station.

may lead to the situation that there may be not sufficient water to fulfill irrigation water demand and consequently agricultural drought may happen. Since the prediction indicates that runoff will increase in summer seasons, one possible solution to the water deficit in the spring season is that, on the precondition avoiding flood disasters, the reservoir should store more water in previous summer for irrigation use in the spring. 


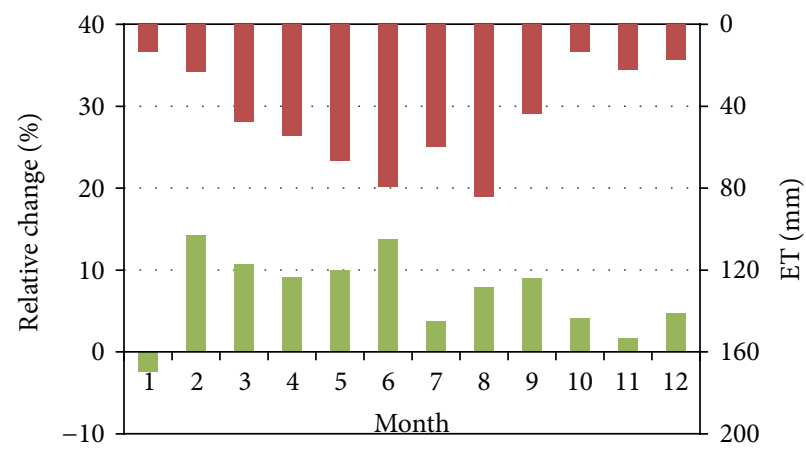

(a)

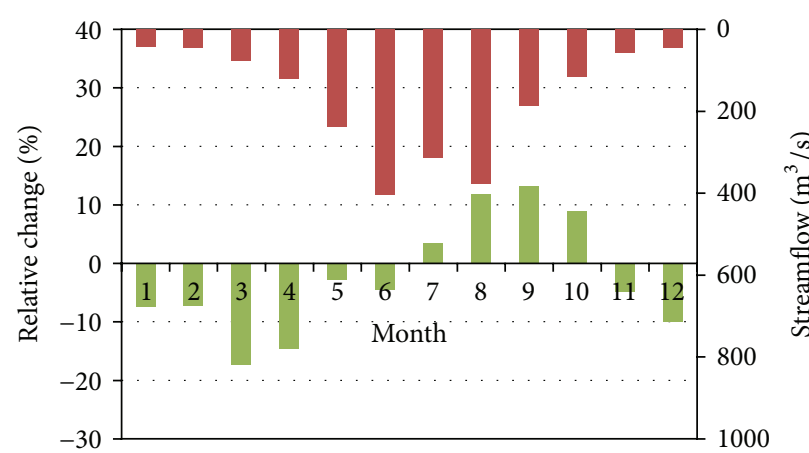

(b)

FIGURE 9: Basin averaged changes (green columns) of monthly mean ET and steamflow at Shilong station between baseline (red columns) and future climate scenario in the 2050s.

\section{Conclusion}

For the purpose of evaluating the influences of climate change on water resources availability in Jinjiang Basin, the BTOPMC hydrological model was applied to simulate the hydrological processes in the basin. By comparing the simulation with observed streamflow data, it is indicated that the model can make fairly reasonable streamflow estimation, justifying using it for hydrological prediction. After constructing regional climate change scenario in the basin, the projected meteorological variables were inputted to BTOPMC model for predicting hydrological processes in the 2050s. The prediction shows that the basin may face water deficit in the spring season and one possible solution is to store more water in the reservoir in previous summer. The results of this study may be valuable for making reasonable water resource management policy in the Jinjiang Basin. To make the policy in a more quantitative manner, an analysis about the amount of water needed for irrigation is needed to decide how much extra water should be stored in the summer season.

\section{Conflict of Interests}

The authors declare that there is no conflict of interests regarding the publication of this paper.

\section{Acknowledgments}

This study was supported by the National Natural Science Foundation of China (Grant no. 41201018), the National Key Technology R\&D Program (Grant no. 2013BAB05B04), and the Fundamental Research Funds for the Central Universities.

\section{References}

[1] Ministry of Water Resources, China Water Resources Bulletin 2011, China Water Power Press, Beijing, China, 2012.

[2] A. Bronstert, V. Kolokotronis, D. Schwandt, and H. Straub, "Comparison and evaluation of regional climate scenarios for hydrological impact analysis: general scheme and application exa- mple," International Journal of Climatology, vol. 27, no. 12, pp. 1579-1594, 2007.

[3] S. Piao, P. Ciais, Y. Huang et al., "The impacts of climate change on water resources and agriculture in China," Nature, vol. 467, no. 7311, pp. 43-51, 2010.

[4] X. Xin, R. Yu, T. Zhou, and B. Wang, "Drought in late spring of South China in recent decades," Journal of Climate, vol. 19, no. 13, pp. 3197-3206, 2006.

[5] Bureau of Water Resources of Quanzhou City, "Supplements to water demand management mechanisms in Quanzhou City," 2010 (Chinese).

[6] T. Ao, J. Yoshitani, K. Takeuchi, K. Fukami, T. Mutsuura, and H. Ishidaira, "Effects of sub-basin scale on runoff simulation in distributed hydrological model: BTOPMC," AISH Publication, no. 282, pp. 227-233, 2003.

[7] K. Takeuchi, P. Hapuarachchi, M. Zhou, H. Ishidaira, and J. Magome, "A BTOP model to extend TOPMODEL for distributed hydrological simulation of large basins," Hydrological Processes, vol. 22, no. 17, pp. 3236-3251, 2008.

[8] S. Shrestha, S. Bastola, M. S. Babel et al., "The assessment of spatial and temporal transferability of a physically based distributed hydrological model parameters in different physiographic regions of Nepal," Journal of Hydrology, vol. 347, no. 1-2, pp. 153$172,2007$.

[9] H. Ishidaira, Y. Ishikawa, S. Funada, and K. Takeuchi, "Estimating the evolution of vegetation cover and its hydrological impact in the Mekong River basin in the 21st century," Hydrological Processes, vol. 22, no. 9, pp. 1395-1405, 2008.

[10] G. Wang, H. A. P. Hapuarachchi, K. Takeuchi, and H. Ishidaira, "Grid-based distribution model for simulating runoff and soil erosion from a large-scale river basin," Hydrological Processes, vol. 24, no. 5, pp. 641-653, 2010.

[11] K. J. Beven and M. J. Kirkby, "A physically based, variable contributing area model of basin hydrology," Hydrological Sciences Bulletin, vol. 24, no. 1, pp. 43-69, 1979.

[12] J. A. Cunge, "On the subject of a flood propagation computation method (Muskingum method)," Journal of Hydraulic Research, vol. 7, no. 2, pp. 205-230, 1969.

[13] FAO/IIASA/ISRIC/ISSCAS/JRC, "Harmonized World Soil Database," version 1. 2, FAO, Rome, Italy and IIASA, Laxenburg, Austria, 2012.

[14] J. Doorenbos and W. O. Pruitt, "Crop water requirements," FAO Irrigation and Drainage Paper 24, FAO, Rome, Italy, 1992. 
[15] M. C. Zhou, H. Ishidaira, H. P. Hapuarachchi, J. Magome, A. S. Kiem, and K. Takeuchi, "Estimating potential evapotranspiration using Shuttleworth-Wallace model and NOAA-AVHRR NDVI data to feed a distributed hydrological model over the Mekong River basin," Journal of Hydrology, vol. 327, no. 1-2, pp. 151-173, 2006.

[16] J. Pinzon, M. E. Brown, and C. J. Tucker, "Satellite time series correction of orbital drift artifacts using empirical mode decomposition," in Hilbert-Huang Transform: Introduction and Applications, N. Huang, Ed., pp. 167-186, World Scientific, Singapore, 2005.

[17] E. P. Maurer, J. C. Adam, and A. W. Wood, "Climate model based consensus on the hydrologic impacts of climate change to the Rio Lempa basin of Central America," Hydrology and Earth System Sciences, vol. 13, no. 2, pp. 183-194, 2009.

[18] F. Giorgi and R. Francisco, "Evaluating uncertainties in the prediction of regional climate change," Geophysical Research Letters, vol. 27, no. 9, pp. 1295-1298, 2000.

[19] G. Fu, S. P. Charles, and F. H. S. Chiew, "A two-parameter climate elasticity of streamflow index to assess climate change effects on annual streamflow," Water Resources Research, vol. 43, no. 11, Article ID W11419, 2007.

[20] N. T. Vanrheenen, A. W. Wood, R. N. Palmer, and D. P. Lettenmaier, "Potential implications of PCM climate change scenarios for Sacramento-San Joaquin River Basin hydrology and water resources," Climatic Change, vol. 62, no. 1-3, pp. 257-281, 2004. 

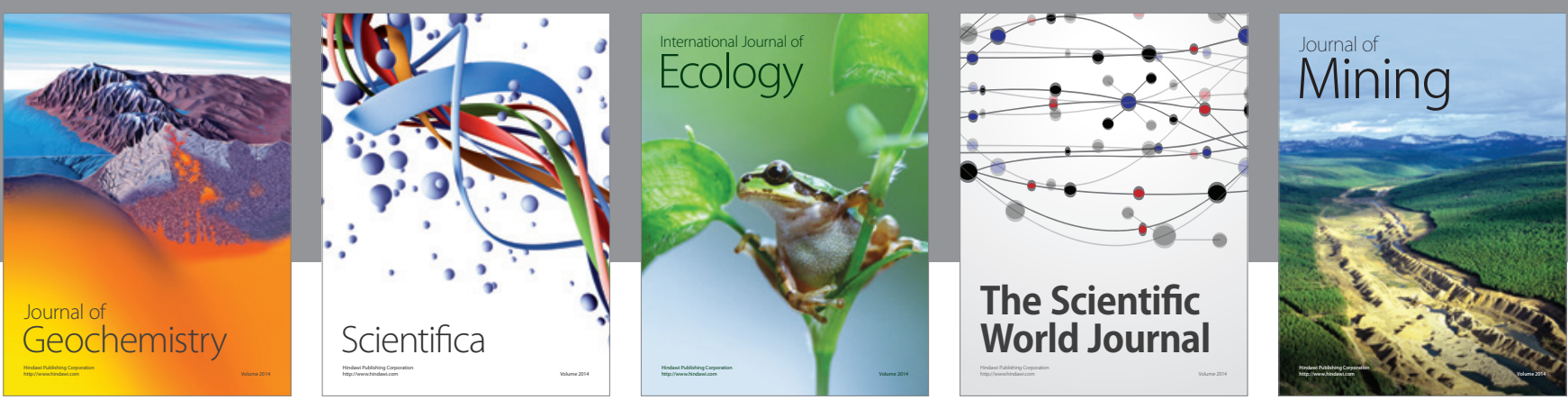

The Scientific World Journal
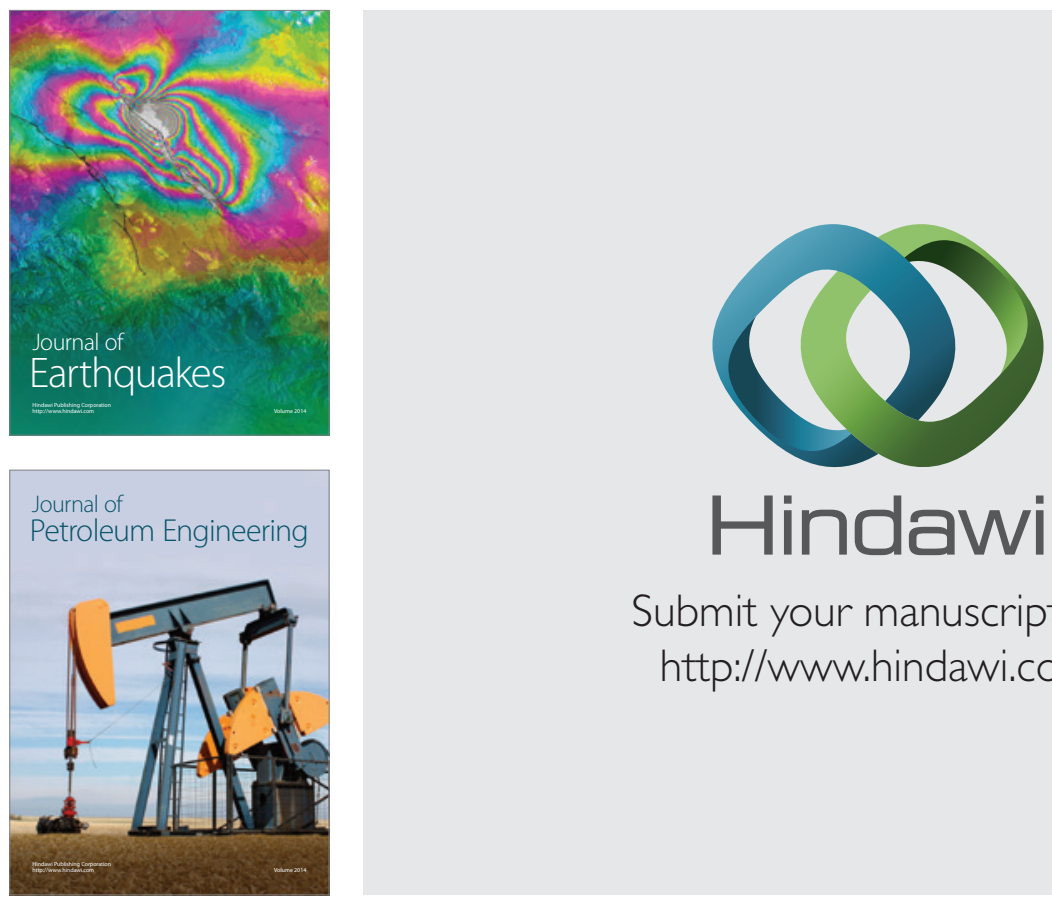

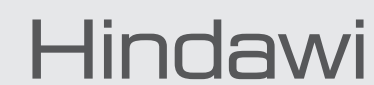

Submit your manuscripts at

http://www.hindawi.com
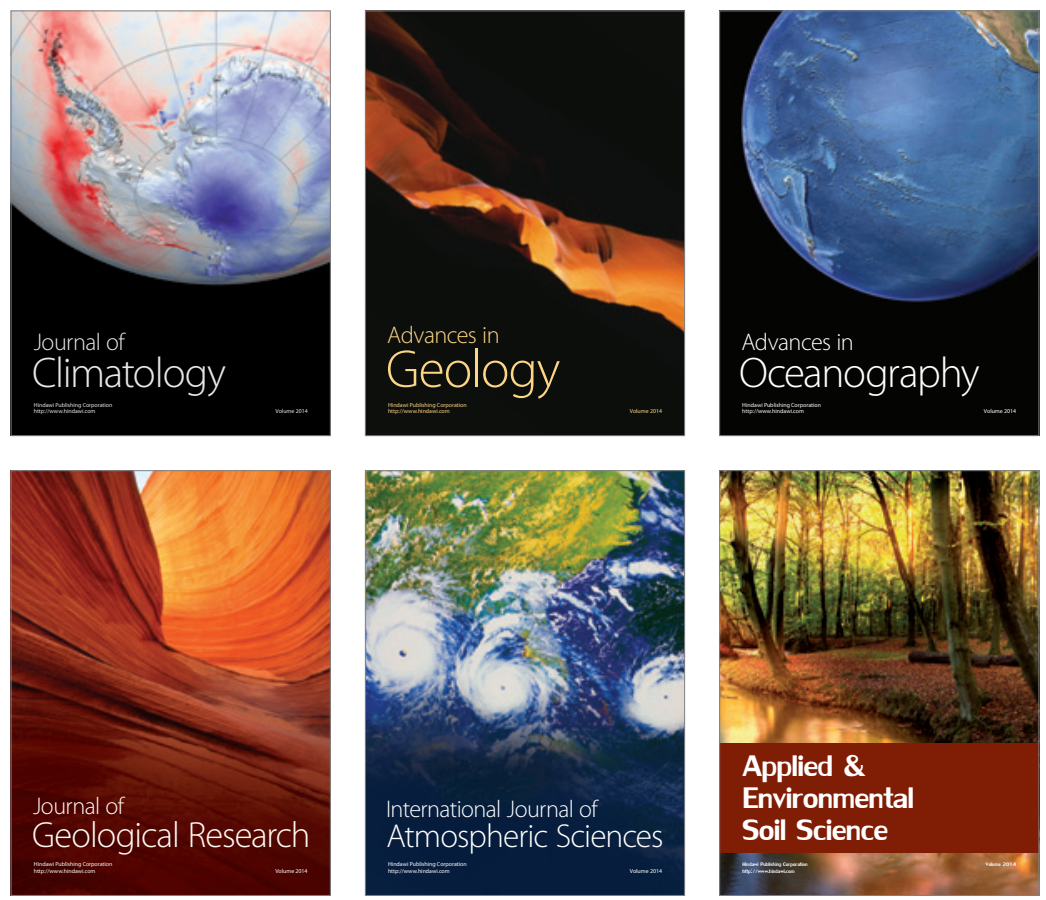
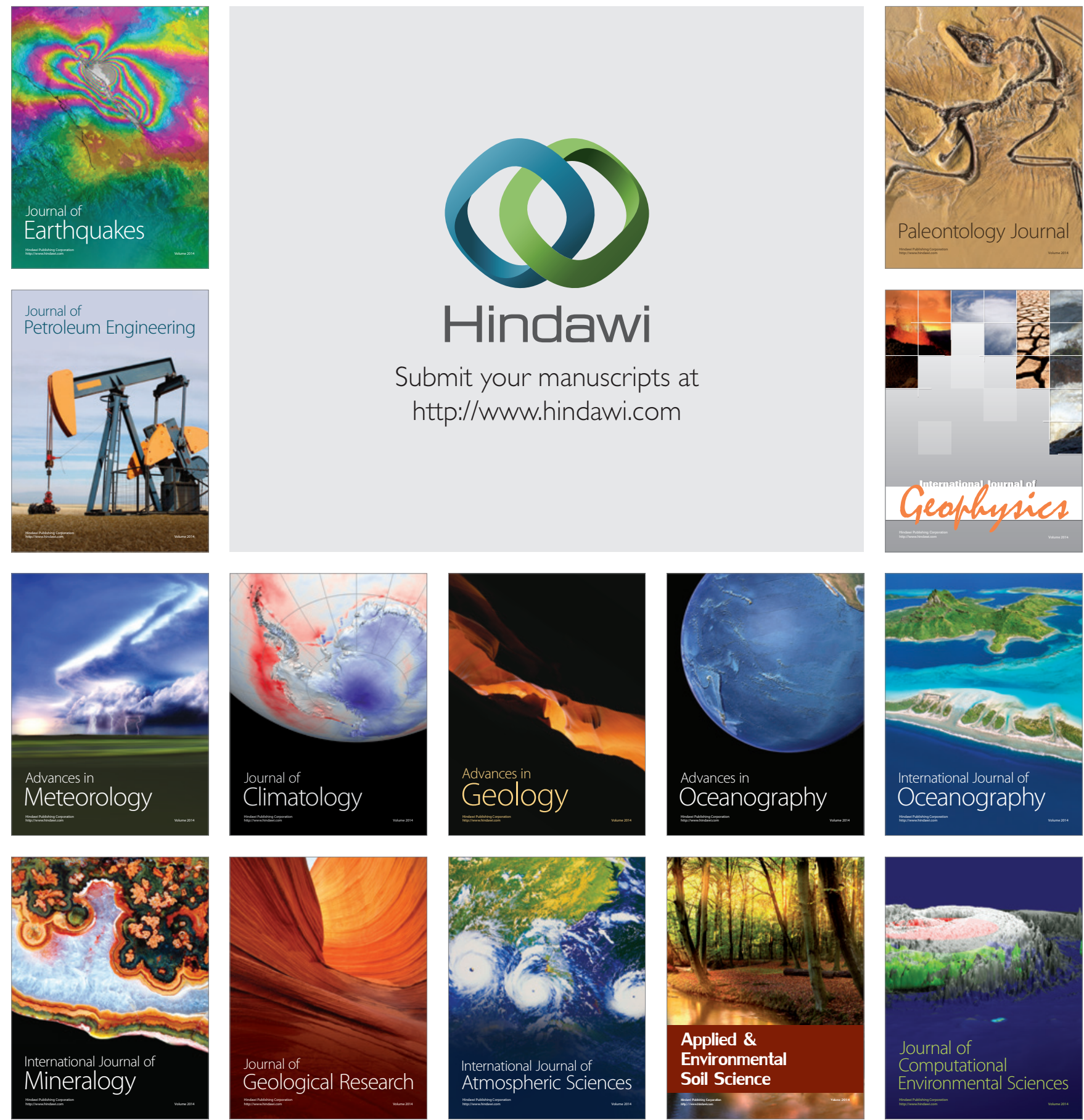